\title{
COMPARATIVE CONVENTIONAL AND MOLECULAR TOOLS FOR DETECTION AND DIFFERENTIATION OF BRUCELLA FIELD AND VACCINAL STRAINS
}

\author{
EMAN S. RAMADAN ${ }^{1}$ and JEHAN A. GAFER ${ }^{2}$ \\ ${ }^{1}$ Reproductive Diseases Dept., Animal Reproduction Research Institute \\ ${ }^{2}$ Biotechnology Unit., Animal Reproduction Research Institute
}

Received: 21 December 2015; Accepted: 14 January 2016

\begin{abstract}
The current study was applied on 111 cows (78 Brucella suspected, 13 vaccinated with S19 and 20 with RB51) for differentiation of Brucella wild and vaccinal strains using conventional and molecular methods (PCR-RFLP, AMOS and real-time PCR). Serum samples were examined using rose Bengal (RBT), tube agglutination and rivanol tests. Milk samples were subjected to milk ring test (MRT), isolation and PCR assays. The diagnostic sensitivity and specificity of RBT were $100 \%$ and $75 \%$ respectively, while MRT were $60 \%$ and $71 \%$ respectively. The highest diagnostic sensitivity and specificity were recorded for PCR (100\% and $82 \%$ ) respectively. Serological tests of vaccinated cows with S19 and RB51 revealed different seropositive and seronegative results respectively for all applied tests. Five isolates of suspected cows were obtained and identified as B.melitensis biovar-3, two isolates of S19 vaccinated cows were obtained and identified as S19, and two isolates of RB51 vaccinated cows (one was identified as RB51 and the other as B.melitensis biovar-3). PCRRFLP assay revealed two patterns (P1 with 238bp and P2 with bands 282, 238bp) were obtained for field B.melitensis and Rev.1 vaccine respectively. AMOS and real-time PCR revealed three different amplicons and three different dissociation peaks respectively specific for different Brucella species. Conclusively, PCR-RFLP can differentiate B.meletensis (wild and vaccinal) and appropriate for application in mixed farms, while AMOSPCR assay is recommended to distinguish between S19 and RB51 vaccinal strains and B.melitensis. The use of more than one method provides a better reliable diagnostic approach for potent improvement of brucellosis control program.
\end{abstract}

Key words: Conventional, Molecular, Brucella field, Vaccinal strains

\section{INTRODUCTION}

Brucellosis is a highly contagious bacterial disease causing significant reproductive losses in animals. In Egypt, despite the implementation of the National Brucellosis Control Program, the disease is still endemic among ruminants and human due to the predominance of smallholdings that favor close contacts between humans and animals and presence of mixed populations of animals, and consumption of unpasteurized milk and dairy products (Hegazy et al., 2011; Holt et al., 2011).

Currently, the diagnosis of brucellosis is based on microbiological and serological laboratory tests. However many serological tests have proved to be either give false-positive, or give false-negative results (Ruiz-Mesa et al., 2005). The gold standard for the diagnosis of brucellosis is isolation. However,

Corresponding author: JEHAN A. GAFER

E-mail address: jehan.gafer@gmail.com

Present address: Biotechnology Unit., Animal Reproduction Research Institute handling live Brucella involves risk of laboratory infection and time consuming. In order to avoid these disadvantages, methods based on the polymerase chain reaction (PCR) are becoming very useful (Ibrahim et al., 2002; Yu and Nielsen, 2010).

PCR-restriction fragment length polymorphism (RFLP) especially of outer membrane protein (OMP) genes of Brucella has been widely and successfully used for genotyping of several Brucella isolates (Cloeckaert et al., 2001).

Brucella AMOS (Abortus, Melitensis, Ovis, Suis) PCR assay is a multiplex PCR designed to detect the IS711 insertion elements in the four brucella species (Ancora et al., 2005).

Real-time PCR constitutes a further technological improvement for the molecular identification of the genus Brucella and the differentiation of its species (Probert et al., 2004).

Vaccination of livestock is the cornerstone for the control and prevention of brucellosis (Cloeckaert et al., 2002). Although the differentiation among vaccine strains and wild-type field isolates of 
Brucella is cumbersome, diagnostic laboratories are presented to distinguish between them due to the possibility of isolation of vaccine strains from milk or other biological samples (Miranda et al., 2015).

Epidemiology of brucellosis is very multifarious due to the probability of involvement of different animal and different Brucella species (Kiril et al., 2015). This reality highlights the importance of the diagnostic procedures for detection and typing of Brucella, as powerful epidemiological tools which are essential for a successful control program. Additionally, the control of human brucellosis remains largely dependent on the control of the disease in animals (Kiril et al., 2015). This study aimed to identify and differentiate vaccinal strains and Brucella species field using conventional and molecular methods PCR-RFLP, AMOS and real-time PCR as a trial for potent improvement of control program of brucellosis.

\section{MATERIALS and METHODS}

Samples: Blood and milk samples were collected aseptically from 111 cows (78 suspected or had history of brucellosis, 13 vaccinated with strain 19 (S19) and 20 vaccinated with strain RB51 (RB51) Table (1).

The serological tests were applied on 111 serum samples using rose bengal test (RBT) (Alton et al., 1988), standard tube agglutination test (SAT) (MacMillan, 1990) and rivanol test (RT) (Alton et al., 1988) was standardized and performed as described by Carpenter (1997). The 111 milk samples were subjected to immunological tests using milk ring test (MRT) as described by (Alton et al., 1988) and were plated onto Brucella agar medium (Oxoid) supplemented with antibiotics at $37{ }^{\circ} \mathrm{C}$ with $5 \% \mathrm{CO} 2$ for 5 to 7 days for isolation. Identification of the isolates was conducted biochemically by routine methods (Alton et al., 1988).

Vaccinal strain: Rev.1 was used in the study as a reference strain

Statistical analysis: Sensitivity and specificity were calculated according to Thrusfield (1986).

Molecular assays: DNA was extracted from bacterial strains by boiling procedure according to Reischl et al. (1994). DNA was extracted from Milk samples with slight modification of Walsh et al.

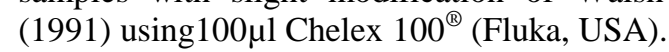

PCR- RFLP assay: This method carried out according to Samadi et al. (2010) by targeting Brucella OMP2 gene and the amplified products were digested using PstI endonuclease enzyme. PCR assay was performed in total volume of $25 \mathrm{ul}$ reaction mix contain 5 ul of template DNA, 20 pmol of each primer Table (2) and 1X of PCR mix (Fermentas). The analysis of PCR products was carried out using $1.5 \%$ ethidium bromide stained agarose gel. Pst $\mathrm{I}$ restriction enzyme was used according to the manufacturer's instruction (Thermo Scientific). Digestion products were electrophoresed using $3 \%$ agarose gel.

AMOS PCR assay: The assay was performed according to Bricker and Halling (1994) using a single reverse primer, targeting the Brucella insertion element IS711, and three different forward primers Table (3). The assay was performed using total volume of 50ul reaction mix contain 5ul of template DNA, 50 pmol of each primer and $1 \mathrm{X}$ of PCR mix.

SYBR Green real time PCR: In an extension of the AMOS-PCR, a multiplex SYBR Green real time PCR was performed. The assay was carried out using Rotor-Gene Q Series (QIAGEN). The assay was performed using total volume of $30 \mathrm{ul}$ reaction SYBR Green Master Mix (Fermentas) contain 5ul of template DNA, 10pmol of each primer (same primer of AMOS assay). After amplification, analysis of melting temperature (Tm) was carried out by continuous recording of fluorescence at gradual increase of temperature $\left(0.2^{\circ} \mathrm{C} / \mathrm{s}\right)$ over the range 50 $95^{\circ} \mathrm{C}$. Thermal profiles of all PCR assays were listed in Table (3).

\section{RESULTS}

Results of 78 serum samples of suspected cows, 23 (29.5\%), $20(25.64 \%)$ and $16(20.5 \%)$ were positive for RBT, SAT and RT respectively. While in milk samples 24 (30.77\%), 5 (6.41) and 18 (23.08\%) were positive for MRT, isolation and PCR respectively Table (4). All five isolates were identified bacteriologically as B.melitensis biovar-3 and by PCR as B.melitensis. The diagnostic sensitivity and specificity of RBT, MRT and PCR compared to bacteriological culture were recorded in Tables (5 and 6) where PCR recorded highest sensitivity $(100 \%)$ and specificity $(82 \%)$.

The diagnostic sensitivity and specificity were determined as $100 \%$ and $86 \%$, respectively for OMP2-PCR assay when the results were compared with the bacterial culture results (5 samples tested positive and 63 samples tested negative with both methods), while in milk samples were $55 \%$ and $98 \%$ respectively when the results were compared with BSCP-PCR assay results (as 10 samples tested positive and 59 samples tested negative with both methods). On the other hand, BSCP-PCR assay demonstrates the same sensitivity and specificity in both cases (bacterial culture or milk samples). 
Results of serology of vaccinated cows, revealed that out of the thirteen vaccinated cows with S19 10 (76.92\%),8 (61.54\%) and $5(38.46 \%)$ were positive using RBT, SAT and RT respectively. The positive results of the thirteen milk samples were $8(61.54 \%)$, $2(15.38 \%)$ and $4(30.77 \%)$ for MRT, isolation and PCR respectively. The two isolates were identified as S19 by bacteriological identification (has the same properties of B. abortus biovar 1strain, but does not require $\mathrm{CO} 2$ for growth, does not grow in the presence of benzyl penicillin $(3 \mu \mathrm{g} / \mathrm{ml})$, thionin blue (2 $\mu \mathrm{g} / \mathrm{ml})$, and ierythritol $(1 \mathrm{mg} / \mathrm{ml})$ and by PCR (gave one specific amplicon of $498 \mathrm{bp}$ ). While, the twenty vaccinated cows with RB51 revealed no positive serological results for RBT, SAT and RT. The positive results in milk samples were $1(5 \%), 2$ $(10 \%)$ and $3(15 \%)$ for MRT, isolation and PCR respectively. The two isolated strains, one of them was identified bacteriologically as B.melitensis biovar-3 and by PCR as B.melitensis, while the other isolate was identified as RB51 by bacteriological identification (rough morphology and growth in the presence of rifampicin ( $250 \mu \mathrm{g}$ per $\mathrm{ml}$ of media) and by PCR (gave two amplicons of 364 and 498bp) Table (7).

In 78 milk samples of (suspected infected cows) studied by BCSP gene based PCR 18 samples could give positive amplification of $223 \mathrm{bp}$ specific for genus Brucella Fig. (1). An amplicon of 731bp specific for B. melitensis was obtained for all the five field isolates and positive milk samples indicating high presence of B. melitensis Fig. (2). However, only10 samples gave positive amplification of $282 \mathrm{bp}$ by using OMP2 gene based PCR Fig. (3). Concerning toPst 1 enzymatic digestion of amplified fragment the results revealed two patterns (P1 and P2), P1 with two bands the large 238bp and the small 44bp (not shown) and P2 with three bands 282, 238 and 44bp Fig. (4). P1 was found in all B. melitensis, S19, RB51 isolates and all milk samples tested positive while P2 was found only in B. melitensis Rev-1 vaccine.

Results of AMOS-PCR revealed specific amplifications of different amplicons, 498bp specific for S19, two amplicons of 498 and 364bp specific for RB51 and an amplicon of $731 \mathrm{bp}$ specific for $B$. melitensis field and vaccinal strains Fig. (5). Regarding to the multiplex SYBR Green real time PCR using the same primer of AMOS the results revealed a fluorescent signal for isolates and Rev-1 vaccine while no fluorescent signals were present in negative control Fig. (6). The analysis of melting curves of the amplified Brucella isolates, yielded three (closely but distinct) dissociation peaks of melt temperatures (Tm) of $80^{\circ} \mathrm{C}$ and $80.5^{\circ}$ Cfor RB51, S19 and $81.2^{\circ} \mathrm{C}$ for Rev-1vaccine and B.melitensis field isolate respectively Fig. (7).

Table 1: Samples and tests used in the study

\begin{tabular}{|c|c|c|c|c|c|c|c|}
\hline \multirow{2}{*}{ Animal status } & \multirow{2}{*}{ Samples } & \multicolumn{6}{|c|}{ Test } \\
\hline & & RBT & SAT & RT & MRT & Isolation & PCR \\
\hline \multirow{2}{*}{ Suspected cows $(n=78)$} & Serum & 78 & 78 & 78 & -- & -- & -- \\
\hline & Milk & -- & -- & -- & 78 & 78 & 78 \\
\hline Vaccinated (S19) & Serum & 13 & 13 & 13 & -- & -- & -- \\
\hline$(n=13)$ & Milk & -- & -- & -- & 13 & 13 & 13 \\
\hline Vaccinated (RB51) & Serum & 20 & 20 & 20 & -- & -- & -- \\
\hline$(n=20)$ & Milk & -- & -- & -- & 20 & 20 & 20 \\
\hline
\end{tabular}

$\mathrm{n}$ : number of animal 
Table 2: Oligonuclutide primers used in the study

\begin{tabular}{|c|c|c|c|}
\hline Target & Sequence (5'-3') & $\begin{array}{l}\text { Amplicon } \\
\text { size }\end{array}$ & Purpose \\
\hline $\begin{array}{l}\text { All brucella } \\
\text { OMP2 }\end{array}$ & $\begin{array}{l}\text { TGGAGGTCAGAAATGAAC } \\
\text { GAG TGC GAA ACG AGC GC } \\
\text { Samadiet al. (2010) }\end{array}$ & $282 b p$ & $\begin{array}{l}\text { Identification and PCR- } \\
\text { RFLP }\end{array}$ \\
\hline $\begin{array}{l}\text { Brucella cell } \\
\text { surface protein } \\
\text { (BCSP) }\end{array}$ & $\begin{array}{l}\text { TGGCTCGGTTGCCAATATCAA } \\
\text { CGCGCTTGCCTTTCAGGTCTG } \\
\text { Mukherjee } \text { et al. (2007) }\end{array}$ & $223 b p$ & Identification \\
\hline B.abortus S19 & $\begin{array}{l}\text { F:GAC GAA CGG AAT TTT TCC AAT } \\
\text { CCC }\end{array}$ & 498bp & \multirow{3}{*}{$\begin{array}{l}\text { AMOS assay and } \\
\text { multiplex SYBR Green } \\
\text { real time PCR }\end{array}$} \\
\hline B. melitensis & F:AAA TCG CGT CCT TGC TGG TCT GA & $731 \mathrm{bp}$ & \\
\hline B. abortusRB51 & $\begin{array}{l}\text { F:CCC CGG AAG ATA TGC TTC GAT CC } \\
\text { R:TGC CGA TCA CTT AAG GGC CTT } \\
\text { CAT } \\
\text { Bricker and Halling (1994); Kumar } \text { et } \boldsymbol{a l} \text {. } \\
\text { (2014) }\end{array}$ & $364 b p$ & \\
\hline
\end{tabular}

Table 3: Thermal profile of PCR assays performed in the study

\begin{tabular}{|c|c|c|c|c|c|c|}
\hline Target & Technique & \multicolumn{4}{|c|}{ Cycling condition } & \multirow[b]{2}{*}{ No. of cycle } \\
\hline \multirow{6}{*}{ OMP2 gene } & \multirow{6}{*}{ PCR-RFLP } & Step & Temp. & \multicolumn{2}{|c|}{ Time } & \\
\hline & & $\begin{array}{c}\text { Initial } \\
\text { denaturation }\end{array}$ & $94^{\circ} \mathrm{C}$ & \multicolumn{2}{|c|}{$4 \mathrm{~min}$} & One cycle \\
\hline & & Denaturation & $94^{\circ} \mathrm{C}$ & \multicolumn{2}{|c|}{$1 \mathrm{~min}$} & \\
\hline & & Anealing & $50^{\circ} \mathrm{C}$ & \multicolumn{2}{|c|}{$1 \mathrm{~min}$} & 35 cycles \\
\hline & & Extension & $72^{\circ} \mathrm{C}$ & \multicolumn{2}{|c|}{$1 \mathrm{~min}$} & \\
\hline & & Final extension & $72^{\circ} \mathrm{C}$ & \multicolumn{2}{|c|}{$10 \mathrm{~min}$} & One cycle \\
\hline \multirow{5}{*}{$\begin{array}{c}\text { Brucellaspecific } \\
\text { insertion } \\
\text { element IS711 }\end{array}$} & \multirow{5}{*}{$\begin{array}{l}\text { AMOS- } \\
\text { PCR and } \\
\text { real time } \\
\text { PCR }\end{array}$} & $\begin{array}{c}\text { Initial } \\
\text { denaturation }\end{array}$ & $95^{\circ} \mathrm{C}$ & $4 \mathrm{~min}$ & $10 \mathrm{~min}$ & One cycle \\
\hline & & Denaturation & $95^{\circ} \mathrm{C}$ & $1.15 \mathrm{~min}$ & $30 \mathrm{~s}$ & \multirow{3}{*}{$\begin{array}{l}35 \text { for AMOS } \\
\text { and } 45 \text { for real } \\
\text { time PCR }\end{array}$} \\
\hline & & Anealing & $55^{\circ} \mathrm{C}$ & $1.15 \mathrm{~min}$ & $45 \mathrm{~s}$ & \\
\hline & & Extension & $72^{\circ} \mathrm{C}$ & $1.30 \mathrm{~min}$ & $60 \mathrm{~s}$ & \\
\hline & & Final extension & $72^{\circ} \mathrm{C}$ & $10 \mathrm{~min}$ & & One cycle \\
\hline
\end{tabular}

Table 4: The prevalence of brucellosis in suspected infected cows

\begin{tabular}{|c|c|c|c|c|c|c|}
\hline \multirow{3}{*}{$\begin{array}{c}\text { Type of samples } \\
\qquad(\mathrm{n}=78)\end{array}$} & \multicolumn{6}{|c|}{ Test Positive } \\
\hline & \multicolumn{3}{|c|}{ Serology } & \multirow{2}{*}{ MRT } & \multirow{2}{*}{ Isolation } & \multirow{2}{*}{ PCR* } \\
\hline & RBT & SAT & RT & & & \\
\hline Serum & $\begin{array}{c}23 \\
(29.5 \%)\end{array}$ & $\begin{array}{c}20 \\
(25.64 \%)\end{array}$ & $\begin{array}{c}16 \\
(20.5 \%)\end{array}$ & -- & -- & - \\
\hline Milk & -- & -- & -- & $\begin{array}{c}24 \\
(30.77 \%)\end{array}$ & $\begin{array}{c}5 \\
(6.41)\end{array}$ & $\begin{array}{c}18 \\
(23.08 \%)\end{array}$ \\
\hline
\end{tabular}


Table 5: Correlation between bacteriological culture with RBT, MRT and PCR results of milk samples of suspected infected cows

\begin{tabular}{|c|c|c|c|c|c|c|c|}
\hline \multirow{2}{*}{ Test } & \multirow{2}{*}{ Result } & \multicolumn{2}{|c|}{ RBT } & \multicolumn{2}{|c|}{ MRT } & \multicolumn{2}{|c|}{ PCR* } \\
\hline & & + & - & + & - & + & - \\
\hline \multirow{2}{*}{ Bacteriological culture } & $+(n=5)$ & 5 & 0 & 3 & 2 & 5 & 0 \\
\hline & $-(n=73)$ & 18 & 55 & 21 & 52 & 13 & 60 \\
\hline Total & 78 & 23 & 55 & 24 & 54 & 18 & 60 \\
\hline
\end{tabular}

Table 6: Sensitivity and Specificity of RBT, MRT, and PCR in comparison with bacteriological culture results

\begin{tabular}{cccc}
\hline Test & Compared with & Sensitivity \% & Specificity \% \\
\hline \multirow{2}{*}{ Bacteriological culture } & RBT & 100 & 75 \\
\cline { 2 - 4 } & MRT & 60 & 71 \\
\hline
\end{tabular}

*: BSCP-PCR assay

Table 7: Prevalence of brucellosis in vaccinated cows

Type of vaccination

\begin{tabular}{|c|c|c|c|c|c|}
\hline \multirow{2}{*}{\multicolumn{2}{|c|}{ Test Positive }} & \multicolumn{2}{|c|}{$\begin{array}{l}\text { Vaccinated with S19 } \\
\qquad(n=13)\end{array}$} & \multicolumn{2}{|c|}{$\begin{array}{l}\text { Vaccinated with RB51 } \\
\qquad(\mathrm{n}=\mathbf{2 0})\end{array}$} \\
\hline & & + Serum & + Milk & +Serum & +Milk \\
\hline \multirow{3}{*}{ Serology } & RBT & $10(76.92 \%)$ & -- & $\mathbf{0}$ & -- \\
\hline & SAT & $8(61.54 \%)$ & -- & $\mathbf{0}$ & -- \\
\hline & RT & $5(38.46 \%)$ & -- & $\mathbf{0}$ & -- \\
\hline \multicolumn{2}{|c|}{ MRT } & -- & $8(61.54 \%)$ & -- & $1(5 \%)$ \\
\hline \multicolumn{2}{|c|}{ Isolation } & -- & $2(15.38 \%)$ & -- & $2(10 \%)$ \\
\hline \multicolumn{2}{|c|}{ PCR* } & -- & $4(30.77 \%)$ & -- & $3(15 \%)$ \\
\hline
\end{tabular}

*: BSCP-PCR assay, $\quad$ n: number of animals 


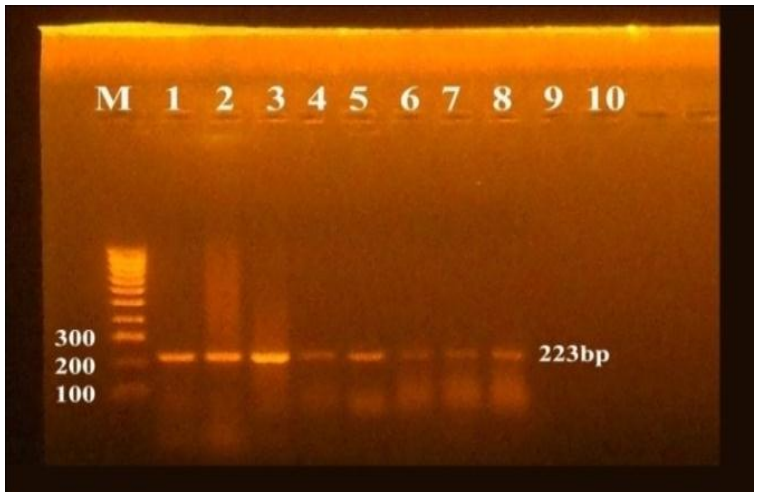

Fig. (1): Ethidium bromide stained $1.5 \%$ agarose gel electrophoresis of bcsp PCR assay of milk samples. Lane M: 100 bp DNA ladder, Lane 1: Positive control, Lanes 2-8: Milk samples. Lane 9: Negative control.

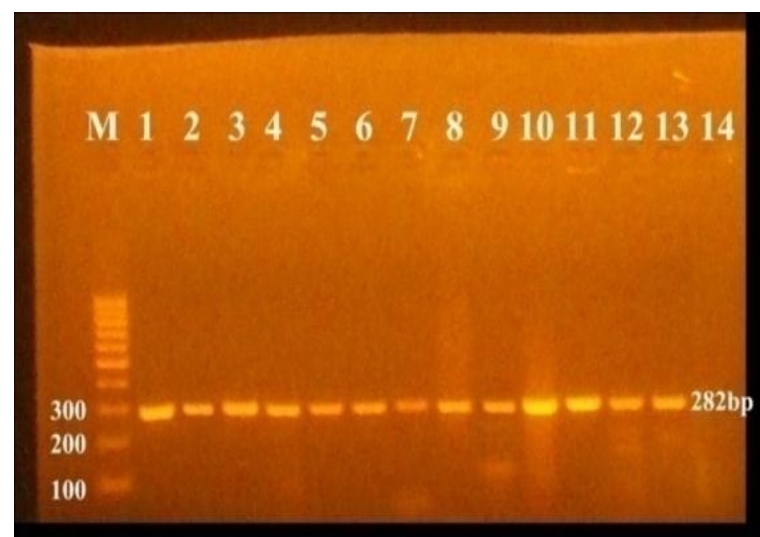

Fig. (3): Ethidium bromide stained $1.5 \%$ agarose gel electrophoresis of OMP2 PCR assay. Lane M: $100 \mathrm{bp}$ DNA ladder, Lane 1: Positive control, Lanes 2-5: Field isolates, Lanes 6-13: Milk samples. Lane 14: Negative control.

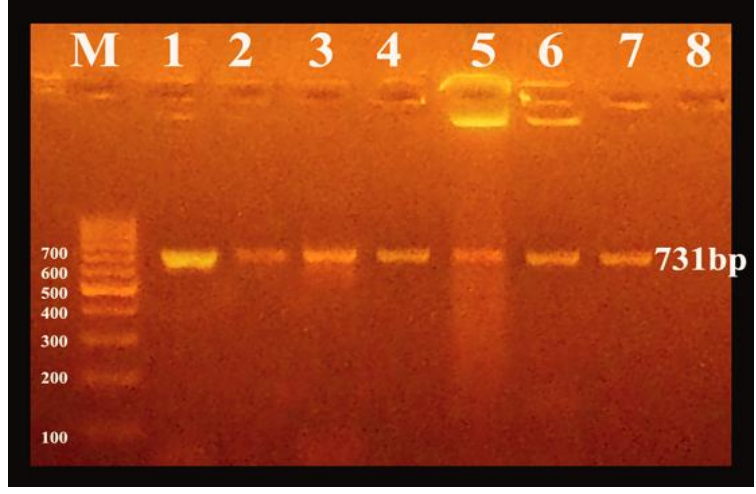

Fig. (2): Ethidium bromide stained 1.5\% agarose gel electrophoresis of PCR-amplified IS711 element specific for $B$. melitensis. The figure shows a specific amplicon of 731-bp DNA. Lane M: 100 bp DNA ladder, Lane 1: Positive control, Lanes 2,3: Field isolates, Lanes 4-7: Milk samples, Lane 8: Negative control.

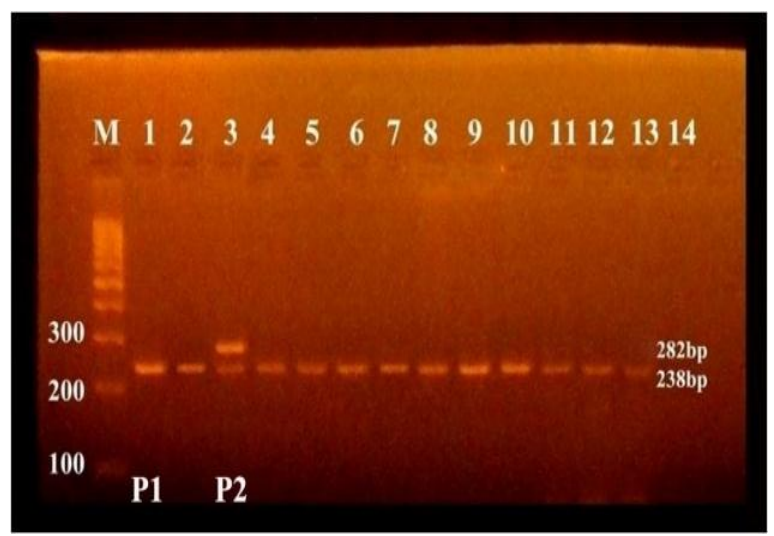

Fig. (4): Ethidium bromide 3\% agarose gel electrophoresis of PCR-RFLP Pst1 digests demonstrates two patterns. Pattern 1 with two bands 238bp and 44bp (not shown). pattern 2 with three bands 282, 238 and 44bp. Lane M: 100 bp DNA ladder, Lane 1: S19, Lane 2: RB51, Lane 3: Rev-1 vaccine, Lanes 4, 5: B. meletinsis field isolates Lane 6-13: Milk samples.

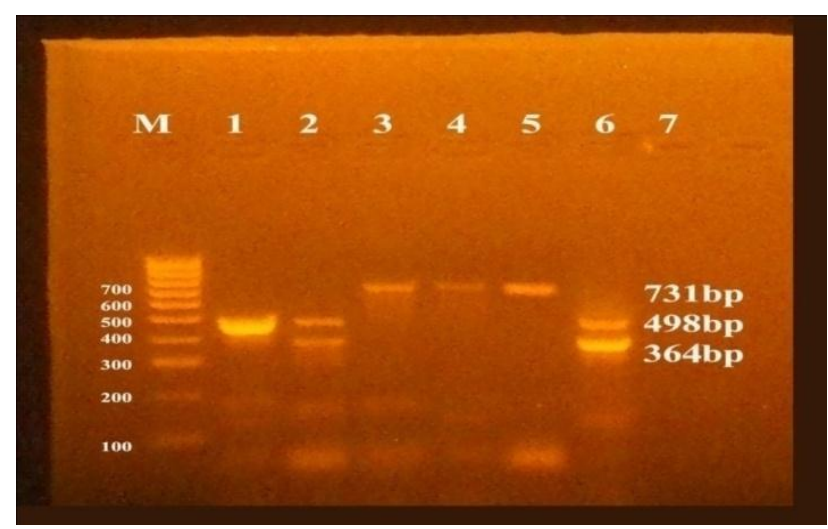

Fig. (5): Ethidium bromide stained 1.5\% agarose gel electrophoresis of AMOS PCR assay Lane M: $100 \mathrm{bp}$ DNA ladder, Lane 1: S19 isolate show one specific band 498bp, Lane 2: RB51 isolate show two specific bands 498 and 364bp, Lane 3: Rev1 vaccine show specific band 731bp, Lane 4,5:B.melitensis field isolates, Lane 6: Milk sample show RB51 pattern. 


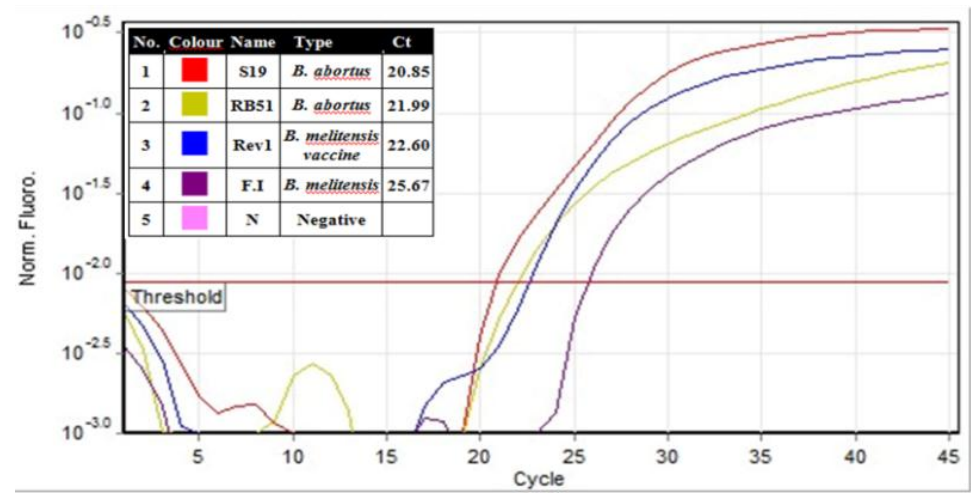

Fig. (6): Amplification curve showing positive amplification of the isolates (S19, RB51 and B. melitensis) and the Rev1 vaccine while negative control shows no amplification.

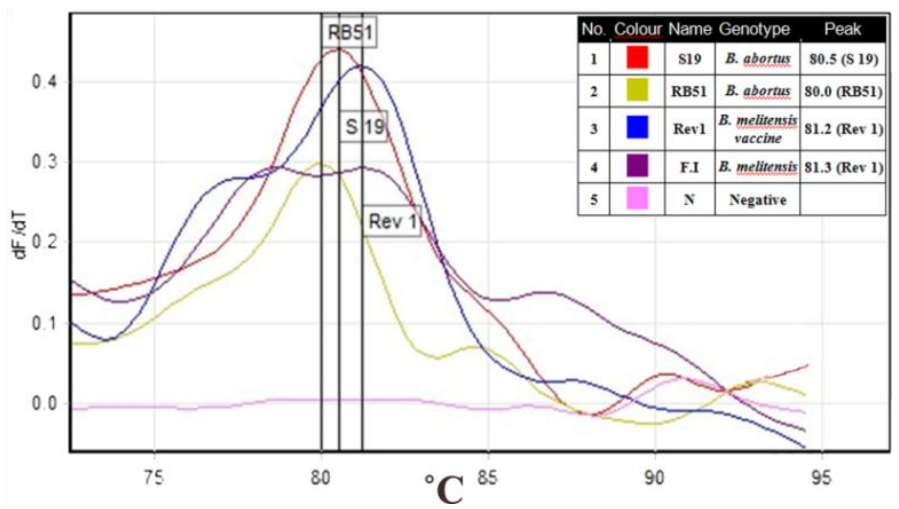

Fig. (7): Dissociation curve analysis of amplified isolates (S19, RB51 and B. melitensis) and Rev1 vaccine. The melting points were demonstrated at the legend at left side.

\section{DISCUSSION}

Brucellosis is one of the world's major zoonoses that still has veterinary, public health and economic concern. The retrospective data of serological tests presented in Table (4) revealed high incidence of brucellosis in Egypt, these results coincided to some extend to what reported before by samaha et al. (2008); Kaoud et al. (2010).

The discrepancy between results of the used serological tests proved that these tests served as important diagnostic aid but is not fully reliable (Akhtar et al., 2010; Eman et al., 2014). The highest positivity was observed with RBT as this test can give false positive reaction. Despite these limitations, RBT may be used as a screening test to ascertain Brucella infection (Kaltungo et al., 2014).

The lowest positivity was observed with RT. This finding was referred to that RT detects principally IgG1 and rivanol test have low sensitivity but high specificity (Acosta-González et al., 2006). It is noticeable from Table (4) that the highest percentage was obtained with MRT, which may be raised from false positives as a result of many causes, including mastitis or hormonal disorder (Bercovich and Moerman, 1979). However, it is cost effective, easy to perform and can cover a large population in a short time (Cadmus et al., 2008).
Culture and isolation of the organism has remained the only unequivocal proof (Poester et al., 2010). Current study revealed only five $(6.41 \%)$ isolates out of 78 milk samples of the suspected cows, this was probably returned to that Brucella was present in very low numbers (O'Leary et al., 2006; Eman et al., 2014). Also, Refai (2003) declared that the sensitivity of the bacteriological culture methods depends on the numbers and viability of Brucella in the sample. Thus, culture methods are not always successful as they are time consuming and the handling of microorganism is hazardous. All five isolates were identified phenotypically as B.melitensis biovar-3 this finding comes in agreement with previous reports that described B.melitensis as the most prevalent in Egypt (Samaha et al., 2008; Eman and Ibrahim, 2014; Menshawy et al., 2014). Unlike isolation, PCR based molecular tests do not require the presence of vital bacteria, can detect bacterial DNA even in the samples with small number of Brucellae, provide quick and objective results and are safe and relatively easy to perform (Poester et al., 2010). The running results revealed higher positivity of PCR assay than culturing method (18 versus to 5), similar finding was achieved previously by Ilhan et al. (2008) who explained that PCR assay can also detect the dead organisms. 
The data illustrated in tables (5 and 6), showed the diagnostic sensitivity of RBT was extreme (100\%) and low specificity (75\%), while MRT gave $60 \%$ sensitivity and $71 \%$ specificity. These results corresponded to Saegerman et al. (2004) who mentioned that these tests showed different sensitivities and specificities depending on numerous variables, such as dose and route infection, the presence cross-reactive bacteria and the kinetics of the induced immune response. The highest diagnostic sensitivity and specificity were recorded for PCR (100\% and $82 \%$ ), respectively this finding agreed with Hamdy and Amin (2002); Gupta et al. (2006); Al-Mariri and Haj-Mahmoud (2010). Moreover, Ibrahim et al. (2002); Alcina et al. (2012) added that because of the high specificity and strict sensitivity, PCR is the only test which was able to detect the occurrence of Brucella organisms in milk samples.

The use of more than one marker-based PCR (BCSP and OMP2) performed in the current study provides a better reliable molecular diagnostic approach for screening of Brucella in field samples, the same attitude was reported by (Mukherjee et al., 2007; Ya and Nielsen 2010).

However, the two genus specific PCR assays clarified that BCSP-PCR assay is more sensitive than OMP2-PCR assay in detecting Brucella in milk samples $(100 \%$ in BCSP versus to $55 \%$ in OMP2PCR assay). Such difference was not seen in both PCR assays when carried out on bacterial isolates, indicating that the presence of host DNA could affect sensitivity of primers, as observed previously by Navarro et al. (2002); Mukherjee et al. (2007) during their studies on bovine blood samples. Similarly, Baddour and Alkhalifa (2008); Ya and Nielsen (2010) reported that the sensitivity vary substantially for the different primers and primer targeting BCSP can provide the greatest sensitivity. Moreover, this difference in both PCR assays may be due to sequence of BCSP gene is better conserved than the OMP2 sequence in the genus Brucella so that, variation in the omp2 sequence has been used as a basis for typing strains (Bardenstein et al., 2002; Mukherjee et al., 2007).

Vaccination of livestock is the cornerstone for the control and prevention of brucellosis but unfortunately, Brucella vaccine could be excreted in cow's milk (Leal-Hernandez et al., 2005). Through the current study, serum samples of vaccinated cows with S19 showed seropositivity for all serological tests (table, 5) this finding agree with earlier report of OIE (2009) that S19 causes persistent titers which could not be distinguished from titers of natural infection because it is a smooth but attenuated strain (Siadat et al., 2012). While serum samples of vaccinated cows with RB51 gave seronegative results for all applied serological tests. This finding was backed to that vaccination with RB51 vaccine did not result in the production of antibodies against the Oside chain of lipopolysaccharide (LPS), as measured by serological tests (Poester et al., 2006).

In the present study, The MRT of vaccinated cows with $\mathrm{S} 19$ and RB51 gave $61.54 \%$ and $5 \%$ positive results, respectively. It is wrong to decide that milk has been found infected with Brucella based on positive MRT results. Indeed, only the presence of anti-Brucella antibodies is detected in milk by the MRT and such antibodies may be induced by vaccination and/or infection with wild type Brucella spp. (Godfroid et al., 2013).

The bacteriological culture of milk samples of vaccinated cows with $\mathrm{S} 19$ revealed (2/13) isolates and were identified as S19 (OIE, 2009). Bricker and Halling (1995) reported that, though S19 can be distinguished from the wild type by culture methods, these methods are not rapid. While, the bacteriological culture of milk samples of vaccinated cows with RB51gave (2/20) isolates, one of them was identified as RB51 (OIE, 2009) and the other isolate was B. melitensis biovar-3 (Alton et al., 1988). The results of PCR showed (4/13) and (3/20) for vaccinated cows with S19 and RB51 respectively this results agreed with the study of ArellanoReynoso et al. (2013). These results declared that these Brucella vaccines could be excreted in cows' milk (Leal-Hernandez et al., 2005; OIE, 2009). It was worth that B.melitesis biovar-3 (wild strain) was isolated from one seronegative RB51 vaccinated cow. This finding was shown before by Samaha et al. (2008). The fact that the negative serology could be due to insufficient number of bacteria to stimulate immunological response capable of generating antibodies feasible for detection by serological tests, although adequate enough to be shed (ArellanoReynoso et al., 2013).

It is significant to declare again that contact between small ruminants and cattle are almost always as the source of B. melitensis infections in cattle (Alvarez et al., 2011). As reported by previous study in Egypt where cattle and buffalo kept in a household with sheep and goats had 6.32 times of testing seropositive for Brucella spp., compared to seronegative (Holt et al., 2011). It is obvious from the results of PCR-RFLP presented in this study Fig. (3) that PCR-RFLP is more suitable for differentiation of ovine and caprine Brucella (vaccinal and field strain) as it could differentiate between $B$. melitensis field isolates (showed P1) and B. melitensis REV-1 vaccine (showed P2). This result is supported by previous result of Bardenstein et al. (2002); Samadi et al. (2010). So it is appropriate for application, especially in mixed farms when raising sheep and/or goats along with cattle or buffalo. By contrast, AMOS-PCR assay was unable to differentiate different $B$. melitensis (vaccinal and field strain) this finding was sustained previously by 
OIE (2013). However, AMOS-PCR can differentiate between different types of S19 and RB51 vaccinal strains and B.melitensis Fig. (5) This result was also reported by previous study of Darla and Betsy (2000).

Comparing to conventional PCR the use of real-time PCR has the major advantage of obtaining results in a shorter time and does not require electrophoresis analysis (Zahidi et al., 2015). This is the first trials to carry out multiplex SYBR Green real time PCR using the same primers of AMOS-PCR technique in differentiating Brucella species. The results revealed three (closely quiet distinct) dissociation peaks of melt temperatures therefore, this assay need more evaluation before introducing to routine identification and differentiation of Brucella species. However, the major advantage of the real-time PCR performed in this study over probe-based genotyping is that it is much cheaper, although some inability to detect very slight changes in melt temperatures. The same opinion was recorded by Gopaul et al. (2014) during their assessment of high resolution melting assay as a tool for rapid identification of Brucella species.

\section{CONCLUSION}

PCR-RFLP assay is appropriate to differentiate ovine and caprine Brucella (vaccinal and field strains) especially in mixed farms. However, AMOS-PCR assay is recommended to distinguish between S19 and RB51 vaccinal strains and B. melitensis. The use of more than one method (conventional and molecular) provides a better reliable diagnostic approach for potent improvement of control program of brucellosis

\section{REFERENCES}

Acosta-González, R.A.; González-Reyes, I. and Flores-Gutiérrez, H. (2006): Prevalence of Brucella abortus antibodies in equines of a tropical region of Mexico The Canadian Journal of Veterinary Research; 70: 302-304.

Akhtar, R.; Chaudhry, Z.I.; Shakoori, A.R.; Ahmad, M.D. and Aslam, A. (2010): Comparative efficacy of conventional diagnostic methods and evaluation of polymerase chain reaction for the diagnosis of bovine brucellosis. Veterinary World.; 3(2): 53-56.

Alcina, V.; Carvalho Netaa, B.; Juliana, P.S.; Mol, A.; Mariana, N. and Xavier, A.; et al. (2012). Review Pathogenesis of bovine brucellosis. The Veterinary Journal 184: 146-155.

Al-Mariri, A. (2015): Isolation of Brucella melitensis strains from Syrian bovine milk samples. Bulgarian Journal of Veterinary Medicine, 18 , No 1, 40-48.

Al-Mariri, A. and Haj-Mahmoud, N. (2010): Detection of Brucella abortus in Bovine Milk by Polymerase Chain Reaction. Acta Vet. Brno, 79: 277-280.
Alton, G.G.; Jones, L.M.; Angus, R.D. and Verger, J.M. (1988): Techniques for the brucellosis laboratory. Institut National de la RechercheAgronomique, Paris, France.

Alvarez, J.; Suaez, J.L.; Garcia, N.; Serrat, C.; Perez-Sancho, $M$. and Gonzalez, S. et al. (2011): Management of an outbreak of brucellosis due to $B$. melitensis in dairy cattle in Spain. Research in Veterinary Science. 90: 208-211.

Ancora, M.; DeSantis, P.; Di Gannatale, E. and Alessiani, A. (2005): Molecular typing of Brucella field strains isolated in Italy. Veterinaria Italiana, 41 (41), 51-55.

Arellano-Reynoso, B.; Suárez-Güemes, F.; Estrada, F.M.; Flores, F.M.; Hernández-Castro, R.; Beltrán Acosta, $R$. and Díaz-Aparicio, $E$. (2013): Isolation of a field strain of Brucella abortus from RB51-vaccinated- and brucellosis-seronegative bovine yearlings that calved normally. Trop Anim Health Prod (2013) 45: 695-697.

Bardenstein, S.; Mandelboim, M., Ficht, T.A.; Baum, M. and Banai, M. (2002): "Identification of the Brucella melitensis vaccine strain Rev.1 in animals and humans in Israel by PCR analysis of the PstI site polymorphism of its omp2 gene," Journal of Clinical Microbiology, vol. 40, no. 4, pp. 1475-1480.

Baddour, MM. and Alkhalifa, DH. (2008): Evaluation of three polymerase chain reaction techniques for detection of Brucella DNA in peripheral human blood. Can J. Microbiol. 54: 352-357.

Bercovich, Z. and Moerman, A. (1979): Non-specific positive milk ring test(s) in tank milk and Estrumater in the treatment of cattle. Tijdschriftvoor Diergeneeskunde 104: 713716.

Bricker, B.J. and Halling, S.M. (1994): Differentiation of Brucella abortus bv. 1, 2, and 4, Brucella melitensis, Brucella ovis, and Brucella suisbv. 1 by PCR. J. Clin. Microbiol., 32, 2660-2666.

Cadmus, S.I.B.; Adesokan, H.K. and Stack, J. (2008): The use of the milk ring test and Rose Bengal test in brucellosis control and eradication in Nigeria. Journal of the South African Veterinary Association, 79: 113-115.

Carpenter, A.B. (1997): Enzyme-linked immunoassays. In Rose NR, editor. Manual of Clinical Laboratory Immunology, 5th edition. ASM Press, Washington DC, 20-29.

Cloeckaert, A.; Verger, J.M.; Grayon, M.; Paquet, J.Y.; Garin-Bastuji, B.; Foster, G. and Godfroid, J. (2001): Classification of Brucella spp. isolated from marine mammals by DNA polymorphism at the omp2 locus. Microbes. Infect., 3, 729-38.

Cloeckaert, A.; Zygmunt, M. and Guilloteau, L. (2002): Brucella abortus vaccine strain RB51 
produces low levels of M-lik O-antigen. Vaccine, 20, 1820-1822.

Godfroid, J.; Al Dahouk, S.; Pappas, G.; Roth, F.; Gift Matope, G. and Muma, J. et al. (2013): A "One Health" surveillance and control of brucellosis in developing countries: Moving away from improvisation. Comparative Immunology, Microbiology and Infectious Diseases, 36, 241-248.

Gupta, V.K.; Deepak, K.; Vermaa, P.K.; Routa, S.V.S. and Vihana, V.S. (2006): Polymerase chain reaction (PCR) for detection of Brucella melitensis in goat milk. Small Rum Res 65: 79-84.

Darla, R.E. and Betsy, J.B. (2000): Validation of the abbreviated brucella AMOS PCR as a rapid screening method for differentiation of Brucella abortus field strain isolates and the vaccine strains, 19 and rb51.Journal of Clinical Microbiology, p. 3085-3086.

Eman, S.R.; Abou-Gazia, K.A. and Ibrahim, I.G.A. (2014): Seroprevalence of brucellosis among suspected case of camels. J. Egypt. Vet. Med. Assoc. 74 (2): 293-303. Proceedings of the $30^{\text {th }}$ Arab Vet. Med. Congress, May 12-14 (2014), Cairo, Egypt.

Eman, S.R. and Ibrahim, I.G. (2014): Role of Rats in spreading of Brucella infection in dairy farms. J. Egypt. Vet. Med. Assoc. 74 (2): 345-360. Proceedings of the $30^{\text {th }}$ Arab Vet. Med. Congress, May 12-14 (2014), Cairo, Egypt.

Gopaul, K.K.; Jessica, S.; Robin, L.; Stephen, M.BS.; Jeffrey, T.F. and Adrian, M.W. (2014): Development and assessment of multiplex high resolution melting assay as a tool for rapid single-tube identification of five Brucella species. Bio Med Central Research note.7: 903, 1-12.

Hamdy, M.E and Amin, A.S. (2002): Detection of Brucella species in the milk of infected cattle, sheep, goats and camels by PCR.Vet. J. 163: 299-305.

Hegazy, Y.M.; Moawad, A.; Osman, S.; Ridler, A. and Guitian, J. (2011): Ruminant brucellosis in the Kafr El Sheikh governorate of the Nile Delta, Egypt: prevalence of a neglected zoonosis. PLoS Neglected Tropical Diseases, article e944.

Holt, H.R.; Eltholth, M.M.; Hegazy, Y.M.; El-Tras, W.F.; Tayel, A.A. and Guitian, J. (2011): Brucella spp. infection in large ruminants in an endemic area of Egypt: cross-sectional study investigating seroprevalence, risk factors and livestock owner's knowledge, attitudes and practices (KAPs). BMC Public Health: 11.

Ibrahim, A.K.; Ibrahim, I.G.A.; Ghoneim, M.A. and Awad, W.S. (2002): Evaluation of polymerase chain reaction (PCR) and conventional diagnostic techniques in milk samples from different animal species. J. Egypt. Vet. Med. Ass.; 62 (2): 119-131.

Ilhan, Z.; Aksakal, A.; Ekin, I.H.; Gulhan, T.; Solmaz, H. and Erdenlig, S. (2008): Comparison of culture and PCR for the detection of Brucella melitensis in blood and lymphoid tissues of serologically positive and negative slaughtered sheep. Lett. Appl. Microbiol, 46(3). 301-306.

Kaltungo, B.Y.; Saidu, S.N.; Sackey, A.K. and Kazeem, H.M. (2014): A review on diagnostic techniques for brucellosis. African Journal of Biotechnology; 13(1): 1-10.

Kaoud, H.A.; Zaki, M.M.; El-Dahshan, A.R.; and Nas, S.A. (2010): Epidemiology of Brucellosis Among Farm Animals. Nature and Science; 8(5):190-197.

Kiril, K.; Ivancho, N.; Dine, M.; Slavcho, M.; Iskra, C. and Aleksandar, J. et al. (2015): Application of fluorescence based molecular assays for improved detection and typing of brucella strains in clinical samples. Mac. Vet. Rev. 38 (2): 223-232.

Kumar, V.G.; Shivasharanappa, N.; Amit, K.; Kumaresan, G.; Ashok, K. and Rajveer, S.P. (2014): Markers for the molecular diagnosis of brucellosis in animals. Advances in Animal and Veterinary Science 2 (3s): 31-39.

Leal-Hernandez, M.; Díaz-Aparicio, E. and Pérez, GR.; et al. (2005): Protection of Brucella abortus RB51 revaccinated cows, introduced in a herd with active brucellosis, with presence of atypical humoral response. Comparative Immunology, Microbiology \& Infectious Diseases, 28, 63-70.

MacMillan, A.P. (1990): Conventional serological tests. Ed. By Nielsen, K. and Ducan, Y.R. In: Animal Brucellosis. Int. Stand. Book No. 08493-58787, Library og Congress, Card No. 89: 95248, USA.

Menshawy, A.M.; Perez-Sancho, M.; Garcia-Seco, T.; Hosein, H.I.; García, N.; Martinez, I.; Sayour, A.E.; Goyache, J.; Azzam, R.A.; Dominguez, L. and Alvarez, J. (2014): Assessment of Genetic Diversity of Zoonotic Brucella spp. Recovered from Livestock in Egypt Using Multiple Locus VNTR Analysis. Biomed Res Int.:353876. doi: 10.1155/2014/353876.

Miranda, K.L.; Dorneles, E.M.; Fernando, P.; Poester, F.P.; Martins Filho, P.S.; Pauletti, R.B.; Andrey, P. and Lage, A.P. (2015): Different resistance patterns of reference and field strains of Brucella abortus. Brazilian Journal of Microbiology 46, 1, 265-269.

Mukherjee, F.; Jain, J.; Patel, V. and Mrinalini, N. (2007): Multiple genus-specific markers in PCR assays improve the specificity and sensitivity of diagnosis of brucellosis in field animals. Journal of Medical Microbiology 56, 1309-1316. 
Navarro, E.; Escribano, J.; Ferna'ndez, J.A. and Solera, J. (2002): Comparison of three different PCR methods for detection of Brucella spp in human blood samples. FEMS Immunol Med Microbiol 34, 147-151.

OIE, (2009): "Terrestrial manual, Bovine brucellosis," in Manual of Diagnostic Tests and Vaccines for Terrestrial Animals, vol. 2, chapter 2.4.3, pp. 624-659, OIE, Paris, France.

O'Leary, S.; Sheahan, M. and Sweeney, T. (2006): Brucella abortus detection by PCR assay in blood, milk and lymph tissue of serologically positive cows. Res. Vet. Sci. 81:170-176.

Poester, F.P.; Goncalves, V.S.; Paixao, T.A.; Renato, L.; Santos, R.L.; Olsen, S.C.; Schurig, G.G.; Andrey, P. and Lage, A.P. (2006): Efficacy of strain RB51 vaccine in heifers against experimental brucellosis. Vaccine 24 5327-5334.

Poester, F.P.; Nielsen, K.; Samartino, L.E and Yu, W.L. (2010): Diagnosis of brucellosis. Open Vet. Sci. J., 4, 46-60.

Probert, W.S.; Schrader, K.N.; Khuong, N.Y.; Bystrom, S.L. and Graves, M.H. (2004): Realtime multiplex PCR assay for detection of Brucella spp., B. abortus, and B. melitensis. J. Clin. Microbiol; 42: 1290-1293.

Refai, M. (2003): Application of biotechnology in the diagnosis and control of brucellosis in the Near East Region. World J. Microbiol. Biotechnol 19: 443-449.

Reischl, U.; Pluz, M.; Ehret, W. and Wolf, H. (1994): PCR-based detection of mycobacteria in sputum samples using a simple and reliable DNA extraction protocol. Bio. Techniques, 17: 844-845.

Ruiz-Mesa, J.D.; Sanchez-Gonzalez, J.; Reguera, J.M.; Martin, L.; Lopez-Palmero, S. and Colmenero, J.D. (2005): Rose Bengal test: diagnostic yield and use for therapid diagnosis of human brucellosis in emergencydepartments in endemic areas. Clin. Microbiol. Infect., 11: 221-225.

Saegerman, C.; De Waele, L.; Gilson, D.; Godfroid, J.; Thiange, P. and Michel, P.; et al. (2004): Evaluation of three serum i-ELISAs using monoclonal antibodies and protein $G$ as peroxidase conjugate for the diagnosis of bovine brucellosis. Vet. Microbiol.; 100: 91105.

Samadi, A.; Ababneh, M.MK.; Giadinis, N.D. and Lafi, S.Q. (2010): Ovine and caprine brucellosis (Brucellamelitensis) in aborted animals in jordanian sheep and goat flocks. Veterinary Medicine International pp. 1-7.

Samaha, H.; Al-Rowaily, M.; Khoudair, RM. and Ashour, HM. (2008): Multicenter study of brucellosis in Egypt. Emerg Infect Dis. 14(12): 1916-1918.

Siadat, S.D.; Salmani, A.S. and Aghasadeghi, M.R. (2012): Brucellosis Vaccines: An Overview, Zoonosis, Dr. Jacob Lorenzo-Morales (Ed.), ISBN: 978-953-51-479-487.

Thrusfield, M. (1986): Veterinary epidemiology. Butterworth Co., London, UK, Pp 175-185.

Walsh, P.S.; Metzger, D.A. and Higuchi, R. (1991): Chelex $100^{\circledR}$ as a medium for simple extraction of PCR-based typing from forensic material. Biotechniques 10, 506-513.

$Y u$, WL. and Nielsen, K. (2010): Review of detection of Brucella spp. by polymerase chain reaction. Croat Med. J.; 51(4): 306-313. Review.

Zahidi, J.M.; Tay, B.Y.; Rohaidah, H.; Azura, M.N.; Siti, H.H. and Norazah, A. (2015): Identification of Brucella spp. isolated from human brucellosis in Malaysia using highresolution melt (HRM) analysis. Diagnostic Microbiology and Infectious Disease 81: 227233.

\section{طرق مقارنتة تقليدية وجزيئية للكثف والتمييز بين العترة الحقلية والعترة اللقاحية لميكروب البروسبلا إيمان شوقت رمضان ، جيهان عبد الله محمد جعزر}

E-mail: jehan.gafer@gmail.com Assiut University web-site: www.aun.edu.eg

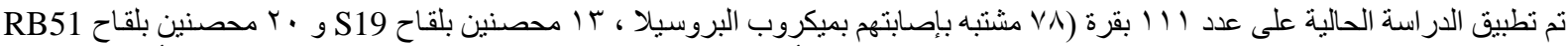

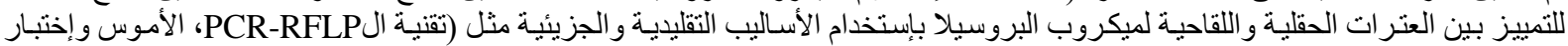

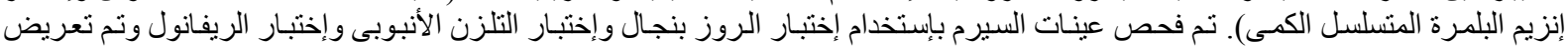

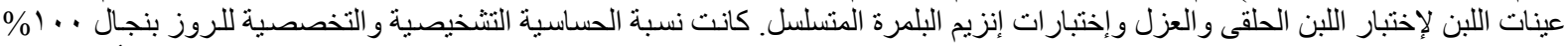

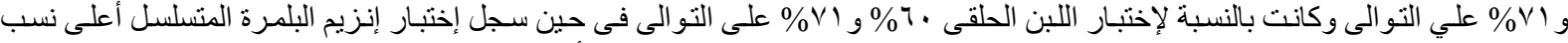

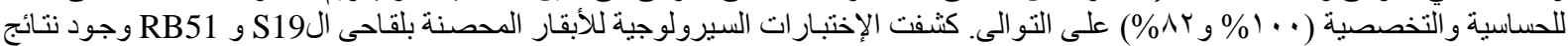

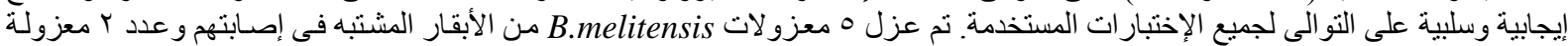

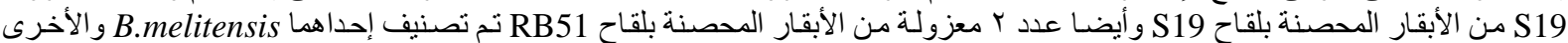

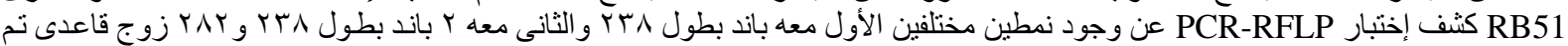

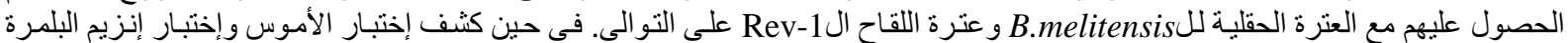

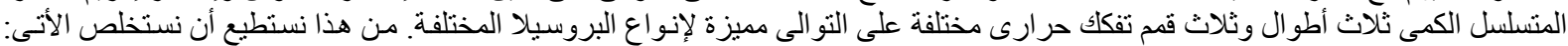

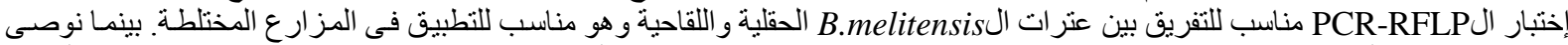

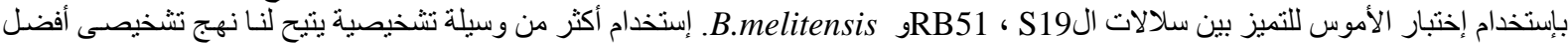
موثوق بـه لتحسين فعال في برنامج مكافحة البروسيلا. 